\title{
Development of PCR-Based Assays for Detecting Xanthomonas campestris pv. carotae, the Carrot Bacterial Leaf Blight Pathogen, from Different Substrates
}

\author{
X. Q. Meng, K. C. Umesh, R. M. Davis, and R. L. Gilbertson, Department of Plant Pathology, University of Cali- \\ fornia, Davis 95616
}

\begin{abstract}
Meng, X. Q., Umesh, K. C., Davis, R. M., and Gilbertson, R. L. 2004. Development of PCRbased assays for detecting Xanthomonas campestris pv. carotae, the carrot bacterial leaf blight pathogen, from different substrates. Plant Dis. 88:1226-1234.

Detection of the carrot bacterial leaf blight pathogen, Xanthomonas campestris pv. carotae, was achieved using polymerase chain reaction (PCR) along with primer pairs developed from sequences of cloned random amplified polymorphic DNA (RAPD) fragments. Primer pairs $3 \mathrm{~S}$ and 9B directed the amplification of $\sim 350$-bp and $~ 900$-bp (or $\sim 2 \mathrm{~kb}$ ) DNA fragments, respectively, from genomic DNA of all known X. campestris pv. carotae strains tested, but not from that of 13 other $X$. campestris pathovars or other bacterial species, including yellow non-xanthomonad bacteria isolated from carrot tissues and seeds. In tests conducted with an extensive collection of $X$. campestris pv. carotae-like strains isolated from different substrates from California, Idaho, Oregon, Washington, and Canada, the $3 \mathrm{~S}$ primer pair directed the amplification of the $\sim 350-\mathrm{bp}$ target fragment from all strains. These results indicated that the $3 \mathrm{~S}$ primer pair is highly specific for $X$. campestris pv. carotae detection. Using the $3 \mathrm{~S}$ primer pair, PCR assays were developed for detection of $X$. campestris pv. carotae from colonies on agar media, carrot leaf and stem tissues, and seeds. These tests could be performed in a single day. The PCR-based seed assay detected $X$. campestris pv. carotae from lots with contamination rates ranging from $2 \times 10^{2}$ to $2.3 \times 10^{8} \mathrm{CFU}$ per gram of seed. This assay gave results similar to a seed-wash dilution plating assay and proved more sensitive than an enzyme-linked immunosorbent assay (ELISA)-based assay.
\end{abstract}

Additional keywords: seedborne pathogen

Bacterial leaf blight of carrot (Daucus carota subsp. sativus), caused by Xanthomonas campestris pv. carotae, is an important seedborne disease with a worldwide distribution. Under favorable conditions, this disease can cause significant yield losses $(8,14,15,17,23,25)$. Foliar symptoms of bacterial leaf blight can be easily confused with other diseases, such as Alternaria leaf blight, particularly early in the season. This complicates disease diagnosis and selection of appropriate disease management strategies.

Contaminated carrot seeds are an important primary source of inoculum for bacterial leaf blight. Therefore, planting seed free of $X$. campestris pv. carotae contamination is an important disease management strategy. However, detection of this pathogen on carrot seeds can be difficult and time-consuming. The most commonly used

Corresponding author: R. L. Gilbertson

E-mail: rlgilbertson@ucdavis.edu

Present address of K. C. Umesh: California Department of Food and Agriculture, 1220 N Street, Room A-372, Sacramento, CA 95814

Accepted for publication 18 June 2004.

Publication no. D-2004-0830-01R

(c) 2004 The American Phytopathological Society method is a seed-wash dilution plating assay, which involves washing seeds in buffer and plating serial dilutions of concentrated or unconcentrated washate on the semi-selective medium, XCS agar (19). After incubation at $28^{\circ} \mathrm{C}$ for 5 days, $X$. campestris pv. carotae colonies are identified based on colony morphology (light yellow, convex, and mucoid). As XCS agar is semi-selective, growth of saprophytic bacteria (including yellow bacteria that are not pathogenic on carrots) can complicate identification. Therefore, pathogenicity tests must be completed to positively identify representative $X$. campestris pv. carotae-like colonies. These tests are laborious, require greenhouse or growth chamber facilities, and take approximately 3 to 4 weeks to complete. A rapid and sensitive method for detection and identification of $X$. campestris pv. carotae colonies on XCS agar medium and/or direct detection from plants or seeds could improve bacterial leaf blight management.

Polymerase chain reaction (PCR) has become a useful tool for detection of plant pathogenic bacteria, including $X$. campestris pathovars $(1,4,7,11,12,20-22)$. In this report, the development and application of a PCR-based method for detection of $X$. campestris pv. carotae is presented, together with methods for detecting the pathogen from agar media, carrot leaf and stem tissues, and seeds.

\section{MATERIALS AND METHODS}

Isolation and characterization of $X$. campestris pv. carotae strains and pathogenicity tests. Five to 10 carrot leaves or umbels with blight symptoms from each carrot field were surfacedisinfested in $5 \%$ sodium hypochlorite for $1 \mathrm{~min}$, rinsed three times in sterilized distilled water, blotted dry, and cut into small pieces with a razor blade. Two or three drops of sterile distilled water were added, and the suspension was streaked onto plates of XCS agar medium. Plates were incubated at $28^{\circ} \mathrm{C}$ for 5 days. $X$. campestris pv. carotae-like colonies (light yellow, convex, and mucoid) were subcultured onto plates of 523 medium (13) and incubated at $28^{\circ} \mathrm{C}$ for 3 to 4 days.

One to three $X$. campestris pv. carotaelike strains from each carrot field or seed lot were selected for pathogenicity tests using a method modified from that of Umesh et al. (23). Cells from a single colony of the strain to be tested were inoculated into $4 \mathrm{ml}$ of $1 \times$ yeast tryptone (YT) broth in a 10-ml culture tube (Fisher Scientific Co., Pittsburg, PA). Tubes were placed on a rotary shaker $(250 \mathrm{rpm})$ and incubated at $28^{\circ} \mathrm{C}$ for 18 to $24 \mathrm{~h}$. These cell suspensions were diluted 20 -fold with sterile water, which generated suspensions of $\sim 1 \times 10^{6} \mathrm{CFU} / \mathrm{ml}$ (based on dilution plating on 523 medium). Carrot seedlings (cv. Caropak) at the 3- to 4-leaf stage ( 35 days old) were sprayed with bacterial suspensions until runoff with a hand-held air pump sprayer. At least 10 carrot seedlings were inoculated with each strain in three independent experiments. Control plants were sprayed with diluted YT broth. Following inoculation, seedlings were covered with a plastic bag and placed in a greenhouse. After $48 \mathrm{~h}$, bags were removed, plants were placed in a mist chamber, and symptom development was assessed 3 to 4 weeks later.

Carrot seed lots and seed-wash dilution plating assay for $X$. campestris pv. carotae. A total of 64 carrot seed lots were obtained from California, Oregon, and Washington during the 2001 to 2003 growing seasons. Seeds were assayed for $X$. campestris pv. carotae using the method of Kuan et al. (14) with minor modifications (23). Briefly, $10 \mathrm{~g}$ of carrot seeds were incubated in $100 \mathrm{ml}$ of $0.85 \% \mathrm{NaCl}$ at $4^{\circ} \mathrm{C}$ 
for 16 to $18 \mathrm{~h}$ in a $250-\mathrm{ml}$ flask. Two drops of Tween 20 were added, and then flasks were placed on a rotary shaker $(250 \mathrm{rpm})$ for $2 \mathrm{~min}$. The seed wash was filtered through four layers of sterilized cheesecloth and centrifuged at $10,000 \times g$ for 10 $\mathrm{min}$. The resulting pellet was resuspended in $10 \mathrm{ml}$ of $0.85 \% \mathrm{NaCl}$, serial dilutions $\left(10^{0}\right.$ to $\left.10^{-5}\right)$ were prepared in $0.85 \% \mathrm{NaCl}$, and $100-\mu \mathrm{l}$ aliquots of each dilution were spread onto each of three plates of XCS agar medium. Plates were incubated at $28^{\circ} \mathrm{C}$ for 5 days, and $X$. campestris pv. carotae-like colonies were counted.

The following tests were done to assess the efficacy of the seed-wash dilution plating assay. The recovery efficiency on XCS agar medium was compared with that on 523 medium by plating dilutions of a strain (Xcc12) on both media in three independent experiments. Also, two seed-wash methods: (i) the standard 16 - to 18 -h wash at $4^{\circ} \mathrm{C}$ and (ii) a 2-h wash at room temperature, were compared in three independent experiments with five seed lots from California and one from Washington, all having different levels of contamination.

Isolation of total genomic DNA from bacterial cells. Total genomic DNA was isolated from cells of $X$. campestris pv. carotae, 13 other known $X$. campestris pathovars, and four other species of bacteria using the method of Audy et al. (4) with minor modifications. Cells from single colonies were inoculated into $8 \mathrm{ml}$ of $1 \times$ YT broth in a $25-\mathrm{ml}$ polypropylene tube (Fisher Scientific Co.). Tubes were placed on a rotary shaker $(250 \mathrm{rpm})$ and incubated at $28^{\circ} \mathrm{C}$ for $24 \mathrm{~h}$. Cell suspensions were transferred into 15-ml polypropylene tubes, and tubes were centrifuged at 9,200 $\times g$ for $10 \mathrm{~min}$. Cell pellets were resuspended in $1 \mathrm{ml}$ of NE buffer $(150 \mathrm{mM}$ $\mathrm{NaCl}, 50 \mathrm{mM}$ EDTA [pH 8.0]), and suspensions were transferred into $1.5-\mathrm{ml} \mathrm{Ep}$ pendorf tubes. Tubes were centrifuged at $10,000 \times g$ for $5 \mathrm{~min}$, and cells were washed with $1 \mathrm{ml}$ of NE buffer and resuspended in $600 \mu$ lof NE buffer containing proteinase $\mathrm{K}$ at $150 \mu \mathrm{g} / \mathrm{ml}$ (BDH, Vancouver, BC, Canada) and $1 \%$ sodium dodecyl sulfate (SDS). This suspension was vortexed for $1 \mathrm{~min}$ and incubated at $50^{\circ} \mathrm{C}$ for $1 \mathrm{~h}$. Cell lysates were extracted twice with an equal volume of phenol/chloroform/isoamyl alcohol (25:24:1), and DNA was recovered by precipitation with isopropanol. The DNA was spooled out with a flame-sealed Pasteur pipette, rinsed in $70 \%$ ethanol, and resuspended in $0.5 \mathrm{ml}$ of TE buffer (10 mM Tris- $\mathrm{HCl}$ [pH 8.0], $1 \mathrm{mM}$ EDTA).

Random amplified polymorphic DNA (RAPD) analysis and cloning and sequencing of RAPD fragments. RAPD analysis of total genomic DNA of selected $X$. campestris pv. carotae strains was performed as previously described for $X$. campestris pv. vitians $(6,7)$ using Operon primer set AB. RAPD products were frac- tionated in $1 \%$ agarose gels in $1 \times$ Tris Borate EDTA (TBE) buffer. Selected RAPD fragments were gel-purified using silica matrix (Geneclean, BIO 101, La Jolla, CA).

RAPD fragments were cloned with the TA cloning system (Invitrogen, San Diego, $\mathrm{CA}$ ), and recombinant plasmids were identified by restriction enzyme digestion with EcoRI (18). Sequences of cloned fragments were determined using the dideoxy nucleotide chain-termination method and Sequenase (USB, Cleveland, OH). Primers were designed from DNA sequences using the software Primer Designer (Version 2.0, Scientific \& Educational Software, Durham, NC).

PCR with $X$. campestris pv. carotae primer pairs and gel electrophoresis. The PCR was carried out in a $50-\mu l$ reaction mixture containing $1 \times$ PCR buffer $(20$ $\mathrm{mM}$ Tris- $\mathrm{HCl}$ [pH 9.0], $37.5 \mathrm{mM} \mathrm{KCl}$, and $7.5 \mathrm{mM}$ Triton X-100); $250 \mu \mathrm{M}$ each of dATP, dCTP, dGTP, and dTTP; $1 \mu \mathrm{M}$ each of forward and reverse primers; 2 units of Taq DNA polymerase (Perkin Elmer Cetus, Emeryville, CA); $4 \mathrm{ng}$ of bacterial total genomic DNA in a DNA Thermal Cycler 480 (Perkin Elmer Cetus), an Eppendorf Mastercycler gradient (Eppendorf Scientific Inc., Westbury, NY), or a Primus 96 plus PCR system (MWG Biotech Inc., High Point, NC). The PCR profile was 30 cycles of $94^{\circ} \mathrm{C}$ for $1 \mathrm{~min}, 65^{\circ} \mathrm{C}$ for $45 \mathrm{~s}$, and $72^{\circ} \mathrm{C}$ for $2 \mathrm{~min}$.

To determine the threshold level of DNA detectable with PCR and various primer pairs, serial dilutions of genomic DNA of $X$. campestris pv. carotae (strain 108-2L21) were prepared and used in the PCR. PCR products were fractionated in $1 \%$ agarose gels in $0.5 \times \mathrm{TBE}$, stained with ethidium bromide, and visualized with an ultraviolet transilluminator (Fisher Scientific Co.) and an IS-1000 Digital Imaging System (Alpha Innotech Corporation, San Leandro, CA).

To test the specificity of the designed primer pair for X. campestris pv. carotae, PCR was conducted using total genomic DNA of one strain of 13 other known $X$. campestris pathovars (X. campestris pv. alfalfae, $X$. campestris pv. cucurbitae, $X$. campestris pv. incanae, $X$. campestris pv. malvacearum, $X$. campestris pv. manihotis, $X$. campestris pv. oryzae, $X$. campestris pv. pelargonii, $X$. campestris pv. phaseoli, $X$. campestris pv. pruni, X. campestris pv. raphani, $X$. campestris pv. translucens, $X$. campestris pv. vesicatoria, and $X$. campestris pv. vitians) and four other species of bacteria (Agrobacterium tumefaciens, Clavibacter michiganensis subsp. michiganensis, Erwinia carotovora subsp. carotovora, and Pseudomonas syringae pv. phaseolicola). The 13 strains of these other $X$. campestris pathovars were kindly provided by L. du Toit (Mount Vernon Research and Extension Unit and Department of Plant Pathology, Washington State Uni- versity). Strains of the four other species of bacteria were from our laboratory.

PCR detection of colonies from agar plates. For detection of colonies, boiled cell extracts of bacterial colonies growing on plates of 523 or XCS agar medium were used as previously described for $X$. campestris pv. vitians (7). Cells were resuspended in $100 \mu \mathrm{l}$ of sterile water prior to boiling.

PCR detection from carrot plant tissues. For detection from carrot plant tissues, plants with bacterial leaf blight symptoms collected from the field or carrot seedlings sprayed with a known strain (01C5L31) in a greenhouse were used. Tissue from seedlings inoculated with sterile distilled water was used as a negative control. Four methods of DNA extraction were tested: (i) The $\mathrm{NaOH}+\mathrm{PVP}$ method of Wang et al. (24), in which 10 $\mathrm{mg}$ of leaf tissue (four or five $\sim 2 \mathrm{~mm}^{2}$ pieces of leaf tissue from borders of diseased and healthy tissue) was placed in an Eppendorf tube, thoroughly ground in 100 $\mu \mathrm{l}$ of $0.5 \mathrm{~N} \mathrm{NaOH}+0.5 \% \mathrm{PVP}$ (wt/vol) with a Kontes pestle, and $5 \mu \mathrm{l}$ of this extract was transferred to another tube with $495 \mu \mathrm{l}$ of $20 \mathrm{mM}$ Tris- $\mathrm{HCl}$ ( $\mathrm{pH} \mathrm{8.0)}$. Two microliters of this extract was used in a 50$\mu \mathrm{l}$ PCR reaction. (ii) The Dellaporta method (10), in which DNA was extracted from 10 to $15 \mathrm{mg}$ of leaf tissue, resuspended in $500 \mu \mathrm{l}$ of sterile water, and $2 \mu \mathrm{l}$ of this DNA extract was used in a $50-\mu l$ PCR reaction. (iii) The CTAB method (26), in which DNA was extracted from 10 to $15 \mathrm{mg}$ of leaf tissue with cetyltrimethylammonium bromide (CTAB) buffer (prewarmed to $60^{\circ} \mathrm{C}$ ), resuspended in $500 \mu$ of sterile water, and $2 \mu \mathrm{l}$ used in a $50-\mu \mathrm{lPCR}$ reaction. (iv) The DNeasy Plant Minikit method (Qiagen Inc., Valencia, CA), in which DNA was extracted from 0.5 to 1.0 $\mathrm{mg}$ of leaf tissue. Tissue was ground into a fine powder in liquid nitrogen with a mortar and pestle, transferred to a 1.5-ml Eppendorf tube, and DNA extracted following manufacturer's instructions. Four microliters of this DNA extract was used in a $25 \mu \mathrm{l}$ PCR reaction. For all four methods, serial dilutions of DNA extracts were also prepared and used in the PCR.

PCR detection from carrot seeds. For detection from carrot seeds by PCR, $10 \mathrm{~g}$ ( $\sim 10,000$ seeds) of seeds were washed as described for the seed-wash dilution plating assay, and the pellet was resuspended in $10 \mathrm{ml}$ of $0.85 \% \mathrm{NaCl}$. From this suspension, 0.5 or $1 \mathrm{ml}$ was added to a $1.5-\mathrm{ml}$ Eppendorf tube, the tube was centrifuged at $10,000 \times g$ for $10 \mathrm{~min}$, and the resulting pellet was used for DNA extraction by four methods: (i) The $\mathrm{NaOH}+$ PVP method (24), in which the pellet was resuspended in $100 \mu \mathrm{l}$ of $0.5 \mathrm{~N} \mathrm{NaOH}+0.5 \% \mathrm{PVP}$ (wt/vol); $5 \mu \mathrm{l}$ of this suspension was added to $495 \mu \mathrm{l}$ of $20 \mathrm{mM}$ Tris- $\mathrm{HCl}$ (pH 8.0), and $2 \mu \mathrm{l}$ of this extract was used in a $50-\mu \mathrm{l}$ PCR reaction. (ii) A modified Dellaporta 
method (10), in which the pellet was resuspended in $600 \mu \mathrm{l}$ of Dellaporta buffer and $1 \%$ SDS, and $2 \mu \mathrm{l}$ of this DNA extract was used in a $50-\mu l$ PCR reaction. (iii) The CTAB method (26), in which the pellet was resuspended in $800 \mu \mathrm{l}$ of $2 \%$ CTAB buffer, and $2 \mu \mathrm{l}$ of this extract was used in a 50- $\mu$ PCR reaction. (iv) The Qiagen DNeasy Tissue Kit method (Qiagen Inc.), in which the pellet was resuspended in 180 $\mu \mathrm{l}$ of ATL buffer (as described in the proto- col for isolation of genomic DNA from gram-negative bacteria), and $4 \mu \mathrm{l}$ of this DNA extract was used in a $25-\mu l$ PCR reaction. For all four methods, serial dilutions of DNA extracts were also prepared and used in the PCR.

To test whether $X$. campestris pv. carotae could be detected from carrot seed with the PCR-based seed assay following a hot water treatment, two seed lots with contamination levels of $1.1 \times 10^{6}$ and $2.3 \times$

Table 1. Geographic location, origin, year of collection, designation, total number, and pathogenicity of Xanthomonas campestris pv. carotae-like strains tested by polymerase chain reaction (PCR) with the $3 \mathrm{~S}$ primer pair in this study

\begin{tabular}{|c|c|c|c|c|c|}
\hline $\begin{array}{l}\text { Geographic } \\
\text { location }\end{array}$ & Origin & $\begin{array}{c}\text { Year of } \\
\text { collection }\end{array}$ & $\begin{array}{l}\text { Designationa (field } \\
\text { or previous name) }\end{array}$ & $\begin{array}{c}\text { Strains } \\
\text { tested } \\
\text { by PCR }\end{array}$ & $\begin{array}{c}\text { Pathogenic } \\
\text { strains/total } \\
\text { strains tested }\end{array}$ \\
\hline \multirow[t]{4}{*}{ Arvin, CA } & Plants & 2001 & AV6 & 15 & $1 / 1$ \\
\hline & & & AV7 & 10 & $1 / 1$ \\
\hline & & 2002 & $108-5$ & 15 & $2 / 2$ \\
\hline & & & $108-10$ & 10 & $2 / 2$ \\
\hline Bakersfield, CA & Plants & 2001 & BK620 & 4 & $1 / 1$ \\
\hline \multirow[t]{12}{*}{ Cuyama, CA } & Unknown & 1990 & Car001 & 1 & $1 / 1$ \\
\hline & Plants & 1999 & $\begin{array}{l}\text { ХCC } 9927-36, \\
\text { ХCС } 9942,43\end{array}$ & 12 & \\
\hline & & 2001 & $01 \mathrm{C} 4$ & 20 & $2 / 2$ \\
\hline & & & $01 \mathrm{C} 5$ & 10 & $1 / 1$ \\
\hline & & & $01 \mathrm{C6}$ & 21 & $1 / 1$ \\
\hline & & 2002 & $02 \mathrm{C} 1$ & 16 & $2 / 2$ \\
\hline & & & $02 \mathrm{C} 2$ & 16 & $2 / 2$ \\
\hline & & & $02 \mathrm{C} 3$ & 16 & $2 / 2$ \\
\hline & & & $02 \mathrm{C} 4$ & 16 & $2 / 2$ \\
\hline & & & $02 \mathrm{C} 5$ & 10 & $2 / 2$ \\
\hline & & & $02 \mathrm{C} 6$ & 10 & $2 / 2$ \\
\hline & & & $02 \mathrm{C} 7$ & 10 & $2 / 2$ \\
\hline Lancaster, CA & Plants & 1999 & $\begin{array}{l}\text { ХСС } 9924-26, \\
\text { ХСС } 9937-41, \\
\text { ХСС } 9958-61\end{array}$ & 12 & \\
\hline \multirow[t]{6}{*}{ Rosedale, CA } & Plants & 2002 & $108-1$ & 14 & $2 / 2$ \\
\hline & & & $108-2$ & 11 & $2 / 2$ \\
\hline & & & $108-3$ & 12 & $2 / 2$ \\
\hline & & & GF11 & 18 & $2 / 2$ \\
\hline & & & GW201A & 15 & $2 / 2$ \\
\hline & & & GWA2J & 15 & $2 / 2$ \\
\hline Idaho & Unknown & 1990 & Car003 & 1 & $1 / 1$ \\
\hline \multirow[t]{15}{*}{ Madras, OR } & Plants & 2001 & $126-6$ & 12 & $1 / 1$ \\
\hline & & & $\mathrm{CF}$ & 16 & $1 / 1$ \\
\hline & & & GLY & 4 & \\
\hline & & & HHL & 11 & $1 / 1$ \\
\hline & & & $\mathrm{H}+\mathrm{T}$ & 14 & $1 / 1$ \\
\hline & & & MS & 14 & $1 / 1$ \\
\hline & & & NMS & 16 & $1 / 1$ \\
\hline & & 2002 & F1 & 10 & $2 / 2$ \\
\hline & & & $\mathrm{F} 2$ & 12 & $2 / 2$ \\
\hline & & & F3 & 12 & $2 / 2$ \\
\hline & & & F4 & 12 & $2 / 2$ \\
\hline & & & F5 & 14 & $2 / 2$ \\
\hline & & & F6 & 12 & $2 / 2$ \\
\hline & & & F7 & 12 & $2 / 2$ \\
\hline & & & F8 & 12 & $2 / 2$ \\
\hline \multirow[t]{9}{*}{ Washington } & Plants & 1994 & Car004 & 1 & \\
\hline & & 1996 & Car005 & 1 & \\
\hline & & 2000 & Car006 & 1 & $1 / 1$ \\
\hline & & & Car007 & 1 & \\
\hline & & 2001 & WA1-12 & 12 & $3 / 3$ \\
\hline & & & WA13-15 & 3 & $1 / 1$ \\
\hline & & & WA21-24 & 4 & $1 / 1$ \\
\hline & & & WA25, 26 & 2 & $1 / 1$ \\
\hline & & 2002 & CAR & 29 & $29 / 29$ \\
\hline \multirow{2}{*}{ Canada } & Unknown & 1990 & Car002 & 1 & $1 / 1$ \\
\hline & & & Total & 548 & 98/98 \\
\hline
\end{tabular}

${ }^{a} X$. campestris pv. carotae strains (Car001-007 and 29 strains from Washington in 2002) were kindly provided by L. du Toit (Mount Vernon Research and Extension Unit and Department of Plant Pathology, Washington State University).
$10^{7} \mathrm{CFU} / \mathrm{g}$ were treated with hot water $\left(52^{\circ} \mathrm{C}\right.$ for $\left.25 \mathrm{~min}\right)$, a treatment known to eradicate $X$. campestris pv. carotae $(3,25)$. To detect the pathogen from these seed lots by PCR, the 2-h seed wash method followed by the Qiagen DNeasy Tissue Kit extraction and PCR was used as described above.

Threshold of detection for the PCR assays. To determine the threshold of detection of $X$. campestris pv. carotae from carrot seed for the PCR-based seed assay, DNA extracts were prepared from seedwash pellets using the $\mathrm{NaOH}+\mathrm{PVP}$, Dellaporta, and CTAB extraction methods from five naturally contaminated seed lots from California. Contamination levels of these seed lots ranged from $2 \times 10^{2}$ to 5.7 $\times 10^{7}$ (determined with the seed-wash dilution plating assay). To assess the threshold in terms of the minimum number of contaminated seeds detectable in 10,000 , one, two, or 10 artificially infested seeds were added to $10 \mathrm{~g}$ of seed previously tested free of $X$. campestris pv. carotae. These lots were washed for 16 to $18 \mathrm{~h}$ at $4^{\circ} \mathrm{C}$, seed-wash pellets were obtained, DNA extracts were prepared from the pellets by the CTAB method, and PCR analysis was performed with the $3 \mathrm{~S}$ primer pair. These assays were performed in three independent experiments, except for the minimum number of contaminated seed, which was conducted twice.

Double antibody sandwich-enzyme linked immunosorbent assay (DASELISA). Polyclonal antiserum against $X$. campestris pv. carotae (strain Xcc12) was made by Antibodies Inc. (Davis, CA) by injecting Giant New Zealand rabbits with heat-killed cells. Immunoglobulin $\mathrm{G}$ (IgG) was purified from crude antisera using the E-Z-Sep kit (Pharmacia Biotech, Alameda, $\mathrm{CA})$ following the manufacturer's instructions. The IgG concentration was adjusted to $1.0 \mathrm{mg} / \mathrm{ml}$ in $0.01 \mathrm{M}$ phosphate buffered saline (PBS), $\mathrm{pH}$ 7.4. An enzyme (alkaline phosphatase)-immunoglobulin conjugate was prepared by the one-step glutaraldehyde method, and the optimum concentration for ELISA was determined as described by Avrameas (5). DAS-ELISA was performed as described by Alvarez and Lou (2) in 96-well flat-bottom polystyrene microtiter plates (Immulon-4, Dynatech Laboratories, Alexandria, VA) with $200 \mu \mathrm{l}$ each of IgG (1:1,000 dilution), seed-wash suspension (prepared as described for the seed-wash dilution plating assay), enzyme conjugate (1:2,000 dilution), and substrate ( $p$-nitrophenyl phosphate, $10 \mathrm{mg} / \mathrm{ml}$ ) per well. The plates were incubated for coating, sample reaction, and enzyme conjugate at $37^{\circ} \mathrm{C}$ for $2 \mathrm{~h}$ or at room temperature for $4 \mathrm{~h}$. The plates were washed between incubation steps with 0.01 M PBS containing $0.5 \%$ Tween 20 using a vacuum/pressure plate washer (Dynatech Ultra Wash II, Dynatech Laboratories, Chantilly, VA). The substrate was allowed 
to react at room temperature for $4 \mathrm{~h}$ before reading color development. The plates were read at $405 \mathrm{~nm}$ on a microplate reader (Molecular Devices, Sunnyvale, CA). Suspensions prepared from carrot seed tested free of $X$. campestris pv. carotae were added to at least six wells per plate as negative controls. Reactions were considered positive if the absorbance values were greater than the mean absorbance plus three times the standard deviation of the negative controls.

\section{RESULTS}

Isolation of strains from carrot plants and seed lots. From 1993 to 1996, 23 X. campestris pv. carotae-like strains were isolated from carrot seed lots or diseased carrot leaves or stems from five locations in California (Cuyama Valley, Davis, Kern County, Madera, and Owens Valley). The identity of these 23 strains as $X$. campestris pv. carotae was confirmed by pathogenicity tests.

Carrot disease surveys were conducted in central Oregon (around Madras) carrot seed production fields on 28 and 29 June 2001 and 8 July 2002. In 2001, $87 X$. campestris pv. carotae-like strains were collected from carrot plants from seven fields (Table 1). In 2002, 96 X. campestris pv. carotae-like strains were collected from carrot plants from eight fields (Table 1). A carrot disease survey was conducted in Washington (around Moses Lake) on 20 July 2001, and $21 X$. campestris pv. carotae-like strains were collected from carrot plants from four of seven fields (Table 1).

$X$. campestris pv. carotae-like strains also were recovered from carrot seed lots. They were recovered from two of four and two of eight selected commercial seed lots planted in California in 2001 and 2002, respectively. Contamination levels ranged from $1.1 \times 10^{2}$ to $6.8 \times 10^{7} \mathrm{CFU} / \mathrm{g}$, and 63 strains of $X$. campestris pv. carotae were collected (Table 2). In 2001, X. campestris pv. carotae-like strains were recovered from 10 seed lots from Oregon. Contamination levels ranged from $6.6 \times 10^{5}$ to 4.0 $\times 10^{8} \mathrm{CFU} / \mathrm{g}$, and 71 strains of $X$. campestris pv. carotae were collected (Table 2). $X$. campestris pv. carotae-like colonies were recovered from 2 of 2 and 8 of 10 seed lots from Washington in 2001 and 2002, respectively. Contamination levels ranged from $3.2 \times 10^{3}$ to $5.7 \times 10^{7} \mathrm{CFU} / \mathrm{g}$, and 134 strains of $X$. campestris pv. carotae were collected (Table 2).

Of the 548 strains isolated from carrot plants (545 strains) or unknown substrates (3 strains) from California, Oregon, and Washington, all 98 strains tested were pathogenic on carrot (Table 1). Of the 268 strains isolated from carrot seed lots, all 16 strains tested were pathogenic on carrot (Table 2).

Generation and testing of primer pairs. RAPD analysis of $X$. campestris pv. carotae genomic DNA with the Operon
$\mathrm{AB}$ primers revealed that primer $\mathrm{AB} 9\left(5^{\prime}-\right.$ GGGCGACTAC-3') directed the amplification of DNA fragments common to all 23 strains collected from California from 1993 to 1996 (data not shown). Two of these fragments ( 400 bp and $\sim 950 \mathrm{bp}$ ) were cloned, and the nucleotide sequences of the ends of each fragment were determined (data not shown). Based on these sequences, the following PCR primer pairs were designed: 3S (3SF: 5'-CATTCCAAGAAGCAGCCA-3' and 3SR: 5'TCGCTCTTAACACCGTCA-3') and 9B (9BF: 5'-TGCCTGGCTACGGAATTA-3' and 9BR: 5'-ATCCACATCCGCAACCAT$\left.3^{\prime}\right)$. When tested with total genomic DNA of the 23 strains collected from California from 1993 to 1996 , the $3 \mathrm{~S}$ primer pair directed the amplification of the $\sim 350$-bp target DNA fragment from all strains, whereas the 9B primer pair directed the amplification of the 2900 -bp target DNA fragment from 18 strains and an $\sim 2 \mathrm{~kb}$ fragment from five strains (data not shown). Representative results for 17 strains from California, Oregon, and Washington are shown in Figure 1A (3S primer pair) and Figure 1B (9B primer pair).

The $3 \mathrm{~S}$ and $9 \mathrm{~B}$ primer pairs were then evaluated for sensitivity based on the capacity to direct the amplification of the target fragment from serial dilutions of total genomic DNA of $X$. campestris pv. carotae (strain 108-2L2-1). In these experiments, the limit of detection (i.e., the smallest amount of DNA from which the target fragment was amplified) for the $3 \mathrm{~S}$ primer pair was $\sim 122 \mathrm{fg}$ of total genomic DNA (Fig. 2A) and $\sim 2 \mathrm{pg}$ for the 9B primer pair (Fig. 2B). Thus, the limit of detection of the $3 \mathrm{~S}$ primer pair was $\sim 20$ fold lower than that of the $9 \mathrm{~B}$ primer pair. The 3S primer pair was selected for subsequent experiments because it: (i) directed the amplification of the same-sized target fragment $(\sim 350 \mathrm{bp})$ from all $X$. campestris pv. carotae strains and (ii) provided greater sensitivity in the PCR.

The $3 \mathrm{~S}$ primer pair did not direct the amplification of DNA fragments from total genomic DNA of strains of 13 other known $X$. campestris pathovars and the four other species of bacteria.

PCR detection from colonies on agar media. In preliminary tests, the $3 \mathrm{~S}$ primer pair directed the amplification of the $\sim 350$ bp target fragment from boiled bacterial cell extracts prepared from single colonies of known strains of $X$. campestris pv. carotae grown on plates of 523 medium (data not shown). Therefore, this method was used to test $X$. campestris pv. carotae-like colonies recovered from different substrates from California, Idaho, Oregon, Washington, and Canada. The 3S primer pair directed the amplification of the $\sim 350$ bp target fragment from all $785 \mathrm{X}$. campestris pv. carotae-like strains collected from carrot plants and seeds from California, Oregon, and Washington in 2001 and 2002, including 704 strains not tested for pathogenicity (Tables 1 and 2). The $3 \mathrm{~S}$ primer pair also directed the amplification of the target fragment from 24 strains col-

Table 2. Geographic location, year of collection, seed lot designation, level of contamination with Xanthomonas campestris pv. carotae, and number and pathogenicity of $X$. campestris pv. carotae-like strains tested by polymerase chain reaction (PCR) with the $3 \mathrm{~S}$ primer pair in this study

\begin{tabular}{|c|c|c|c|c|c|}
\hline $\begin{array}{l}\text { Geographic } \\
\text { location }\end{array}$ & $\begin{array}{c}\text { Year of } \\
\text { collection }\end{array}$ & $\begin{array}{c}\text { Seed lot } \\
\text { designation }\end{array}$ & $\begin{array}{c}\text { Level of } \\
\text { contamination } \\
(\text { CFU/g of seed })^{\mathrm{a}}\end{array}$ & $\begin{array}{c}\text { Strains } \\
\text { tested } \\
\text { by PCR }\end{array}$ & $\begin{array}{c}\text { Pathogenic } \\
\text { strains/total } \\
\text { strains tested }\end{array}$ \\
\hline \multirow[t]{3}{*}{ Cuyama, CA } & 2001 & GP6 & $6.8 \times 10^{7}$ & 15 & $3 / 3$ \\
\hline & & HRR & $1.5 \times 10^{8}$ & 18 & $3 / 3$ \\
\hline & 2002 & SK & $1.1 \times 10^{4}$ & 20 & $2 / 2$ \\
\hline Rosedale, CA & 2002 & PS1202 & $1.0 \times 10^{2}$ & 10 & $2 / 2$ \\
\hline \multirow{10}{*}{ Madras, OR } & 2001 & Xcc1 & $2.3 \times 10^{8}$ & 8 & \\
\hline & & $\mathrm{Xcc} 2$ & $1.0 \times 10^{7}$ & 6 & \\
\hline & & Xcc3 & $4.0 \times 10^{8}$ & 7 & \\
\hline & & Xcc4 & $3.7 \times 10^{6}$ & 5 & \\
\hline & & $1 \mathrm{~L}$ & $9.8 \times 10^{5}$ & 7 & $1 / 1$ \\
\hline & & $2 \mathrm{~L}$ & $6.6 \times 10^{5}$ & 4 & $1 / 1$ \\
\hline & & $1 \mathrm{M}$ & $1.4 \times 10^{6}$ & 9 & $1 / 1$ \\
\hline & & $2 \mathrm{M}$ & $4.7 \times 10^{6}$ & 6 & $1 / 1$ \\
\hline & & $1 \mathrm{H}$ & $2.7 \times 10^{7}$ & 9 & $1 / 1$ \\
\hline & & $2 \mathrm{H}$ & $2.8 \times 10^{6}$ & 10 & $1 / 1$ \\
\hline \multirow[t]{11}{*}{ Washington } & 2001 & WASD2 & $3.2 \times 10^{3}$ & 20 & \\
\hline & & WASD3 & $2.4 \times 10^{4}$ & 20 & \\
\hline & 2002 & WB & $3.2 \times 10^{6}$ & 12 & \\
\hline & & WC & $6.3 \times 10^{5}$ & 12 & \\
\hline & & WD & $3.6 \times 10^{7}$ & 12 & \\
\hline & & WE & $3.5 \times 10^{6}$ & 10 & \\
\hline & & WF & $1.0 \times 10^{6}$ & 12 & \\
\hline & & WG & $1.1 \times 10^{6}$ & 12 & \\
\hline & & WK & $2.3 \times 10^{7}$ & 12 & \\
\hline & & WL & $5.7 \times 10^{7}$ & 12 & \\
\hline & & & Total & 268 & $16 / 16$ \\
\hline
\end{tabular}

\footnotetext{
${ }^{a}$ Level of contamination presented as CFU per gram of seed as determined by the seed-wash dilution
} plating assay. 
lected from California in 1999 (Table 1) and the seven $X$. campestris pv. carotae strains from California, Idaho, Washington, and Canada provided by L. du Toit (Table 1). These results confirmed that these strains were $X$. campestris pv. carotae, and that the $3 \mathrm{~S}$ primer pair has the capacity to direct the amplification of the target fragment from a diversity of $X$. campestris pv. carotae strains.

During the course of isolating $X$. campestris pv. carotae from carrot plants and seeds, bacteria with different colony morphologies (e.g., yellow nonmucoid, white mucoid, and white flat and nonmucoid) were isolated. When two to five colonies representing these types were tested by PCR with the $3 \mathrm{~S}$ primer pair, no DNA fragments were amplified. These results were consistent with the specificity of the $3 \mathrm{~S}$ primer pair for detection of $X$. campestris pv. carotae.

PCR detection from carrot tissues. The target fragment was amplified with the
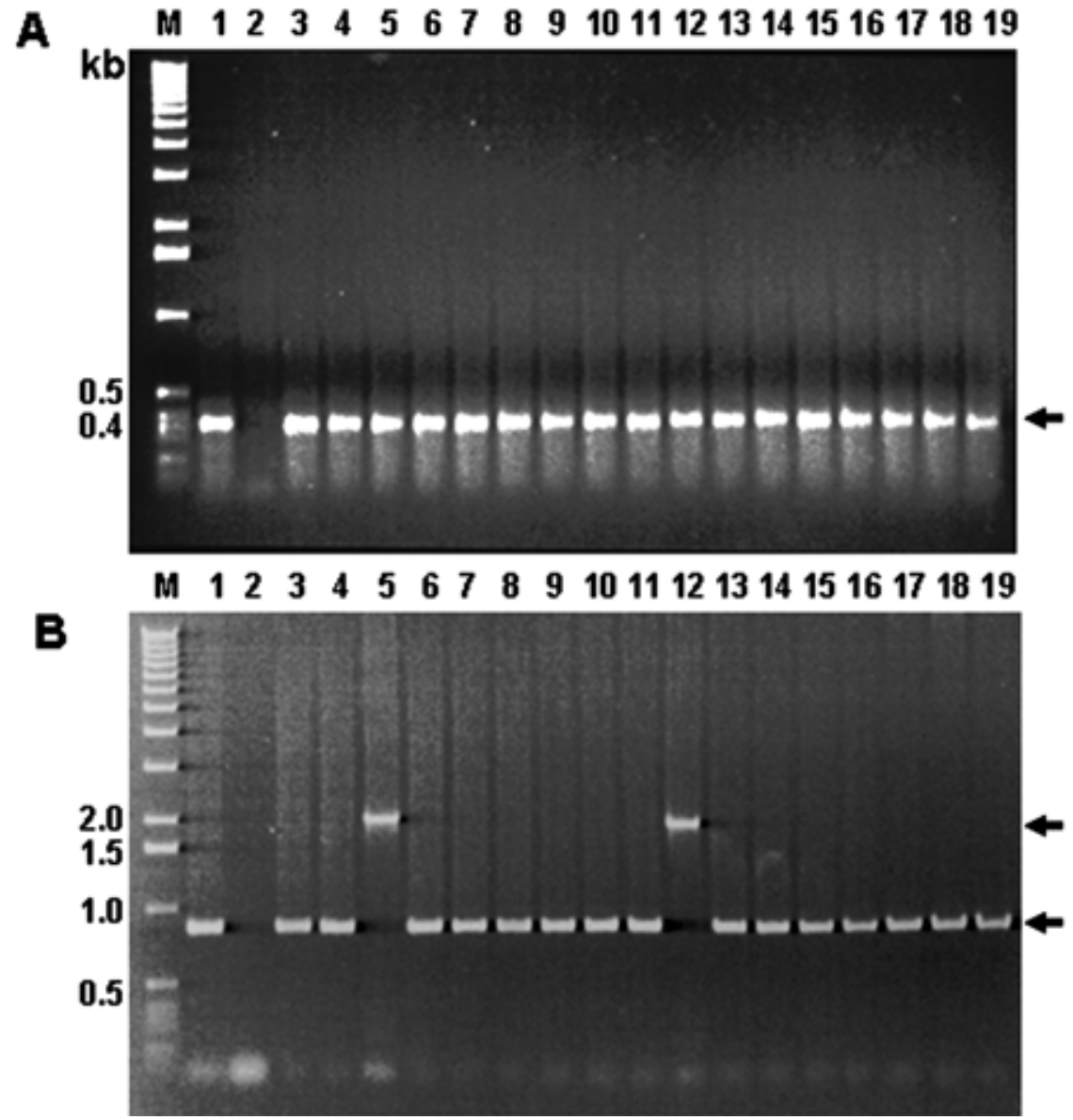

Fig. 1. Agarose gels showing polymerase chain reaction (PCR) with total genomic DNA of Xanthomonas campestris pv. carotae strains and the $\mathbf{A}, 3 \mathrm{~S}$ and $\mathbf{B}, 9 \mathrm{~B}$ primer pairs. Lane $\mathrm{M}$ contains DNA size markers (1-kb DNA ladder, Gibco BRL). Lane 1 is a positive control (PCR with genomic DNA of known strain XCC9940) showing amplification of the $\sim 350$-bp target fragment with the $3 \mathrm{~S}$ primer pair (A), or the $\sim 900$-bp (or $\sim 2 \mathrm{~kb}$ ) target fragment with the 9B primer pair (B). Lane 2 is a negative control (PCR with sterile $\mathrm{H}_{2} \mathrm{O}$ ). Lanes 3 to 5 are strains 108-2L2-1, C4L1-1, and GWA2J-1 from California carrot plants; lanes 6 to 8 are strains GP6-2, GP6-6, and HRR4 from carrot seed lots planted in California; lanes 9 to 11 are strains NMSL1-1, NMSL2-2, and HHLU2-3 from Oregon carrot plants; lanes 12 to 14 are strains $2 \mathrm{~L}-1,2 \mathrm{M}-1$, and $1 \mathrm{H}-14$ from carrot seed lots produced in Oregon; lanes 15 to 17 are strains WA1, WA10, and WA21 from Washington carrot plants, and lanes 18 to 19 are strains WASD2-6 and WASD3-9 from carrot seed lots produced in Washington. higher than that on XCS agar medium. In dilution plating experiments, an average of $6.5 \times 10^{5} \mathrm{CFU} / \mathrm{g}$ was recovered on 523 medium compared with $1.5 \times 10^{5} \mathrm{CFU}$ on XCS agar medium; this represents an $\sim 77 \%$ reduction in plating efficiency on XCS agar medium.

There was no difference in recovery from seed with the standard 16- to 18-h wash at $4^{\circ} \mathrm{C}$ compared with a 2-h wash at room temperature for five contaminated seed lots from California in three independent experiments (data not shown). In similar experiments performed with a contaminated seed lot from Washington, an average of $2.3 \times 10^{7} \mathrm{CFU} / \mathrm{g}$ (three independent experiments) was recovered using both seed wash methods. These results indicate that the 2-h wash is sufficient for recovering $X$. campestris pv. carotae from carrot seed.

For PCR detection of $X$. campestris pv. carotae from seeds, DNA extracts were prepared from seed wash pellets from seed lots with contamination levels ranging from $2.3 \times 10^{2}$ to $5.7 \times 10^{7} \mathrm{CFU} / \mathrm{g}$ using the $\mathrm{NaOH}+\mathrm{PVP}$, Dellaporta, and CTAB methods. The target fragment was amplified with the $3 \mathrm{~S}$ or $9 \mathrm{~B}$ primer pair from extracts prepared with all three methods (data not shown); however, amplification of the target fragment was usually from diluted rather than undiluted extracts, indicating the presence of PCR inhibitors. The detection threshold was $5.8 \times 10^{3} \mathrm{CFU} / \mathrm{g}$ with the $\mathrm{NaOH}+\mathrm{PVP}$ method, and $2.3 \times$ $10^{2} \mathrm{CFU} / \mathrm{g}$ with the CTAB and Dellaporta methods. Using the CTAB method, a single infected seed was detected in $10 \mathrm{~g}$ of seed ( 10,000 seeds). Based on the seedwash dilution plating assay, the contamination level of this lot was $6.2 \times 10^{2} \mathrm{CFU} / \mathrm{g}$.

Because it became commercially available during the course of this study, the Qiagen DNeasy Tissue Kit was investigated as a method to prepare DNA extracts from seed-wash pellets. In three independent experiments, the target fragment was amplified with the $3 \mathrm{~S}$ primer pair from extracts prepared from pellets from seed lots with contamination levels of $2.7 \times 10^{7}$, $2.8 \times 10^{6}$, and $2.0 \times 10^{2} \mathrm{CFU} / \mathrm{g}$ (Fig. 4). As with the other DNA extracts prepared from leaves or seed, amplification of the target fragment was usually from diluted rather than undiluted extracts.

The two seed-wash methods (16 to $18 \mathrm{~h}$ at $4{ }^{\circ} \mathrm{C}$ and $2 \mathrm{~h}$ at room temperature) were compared with the Qiagen DNeasy Tissue Kit DNA extraction method for PCR detection of $X$. campestris pv. carotae from two seed lots with contamination levels of 1.1 $\times 10^{6}$ and $2.3 \times 10^{7} \mathrm{CFU} / \mathrm{g}$. In three independent experiments, the target fragment was amplified from extracts prepared from both seed lots using each seed-wash method (Fig. 5). Thus, there was no difference between these seed-wash methods for PCR detection of $X$. campestris pv. carotae from seed. 
When the two hot water treated seed lots were assayed with the seed-wash dilution plating method, no $X$. campestris pv. carotae colonies were recovered. However, when assayed with the PCR-based seed assay (the 2-h seed wash method followed by the Qiagen DNeasy Tissue Kit extraction), the target fragment was amplified from diluted extracts $\left(10^{-1}\right.$ to $\left.10^{-5}\right)$ prepared from both seed lots treated with hot water. Therefore, $X$. campestris pv. carotae was detected by PCR from hot water treated seed from which viable bacteria were no longer recovered with the seedwash dilution plating assay.

Finally, the seed-wash dilution plating and PCR-based assays were each used to assay 17 carrot seed lots intended for planting in California during the 2001 to 2003 growing seasons. With the seed-wash dilution plating assay, $X$. campestris pv. carotae was recovered from four of the 17 seed lots (contamination levels ranging from $2 \times 10^{2}$ to $1.5 \times 10^{8} \mathrm{CFU} / \mathrm{g}$ ). These same four seed lots also were positive for $X$. campestris pv. carotae by the PCRbased seed assay. The pathogen was not recovered/detected from the other 13 seed lots with the seed-wash dilution plating assay/PCR-based seed assay. Thus, the two tests gave similar results for these seed lots.

Detection from carrot seed with a DAS-ELISA assay. Color development (positive reaction for $X$. campestris pv. carotae) was observed from seed wash suspensions prepared from seed lots with contamination levels $>10^{5} \mathrm{CFU} / \mathrm{g}$. The absorbance values of seed wash suspensions from seed lots having contamination levels $<10^{4} \mathrm{CFU} / \mathrm{g}$ did not differ from those of seed wash suspensions prepared from lots tested free of $X$. campestris pv. carotae contamination (data not shown).

\section{DISCUSSION}

Effective management of bacterial leaf blight begins with the planting of seed lots tested free of contamination. Our disease survey results in central Oregon, which showed a high incidence of bacterial leaf blight and seed contamination by $X$. campestris pv. carotae in this major carrot seed production area, demonstrate the need for effective methods for detection of contamination of carrot seeds by X. campestris pv. carotae. The seed-wash dilution plating assay, together with pathogenicity testing of representative $X$. campestris pv. carotae-like colonies, is currently the standard method of detection $(9,14)$. While generally effective, this approach is laborious and time-consuming, often taking as long as 1 month to complete. Thus, development of more rapid PCR-based methods for detection and identification of $X$. campestris pv. carotae and of seed contaminated by this pathogen should improve the capacity to detect and manage bacterial leaf blight.

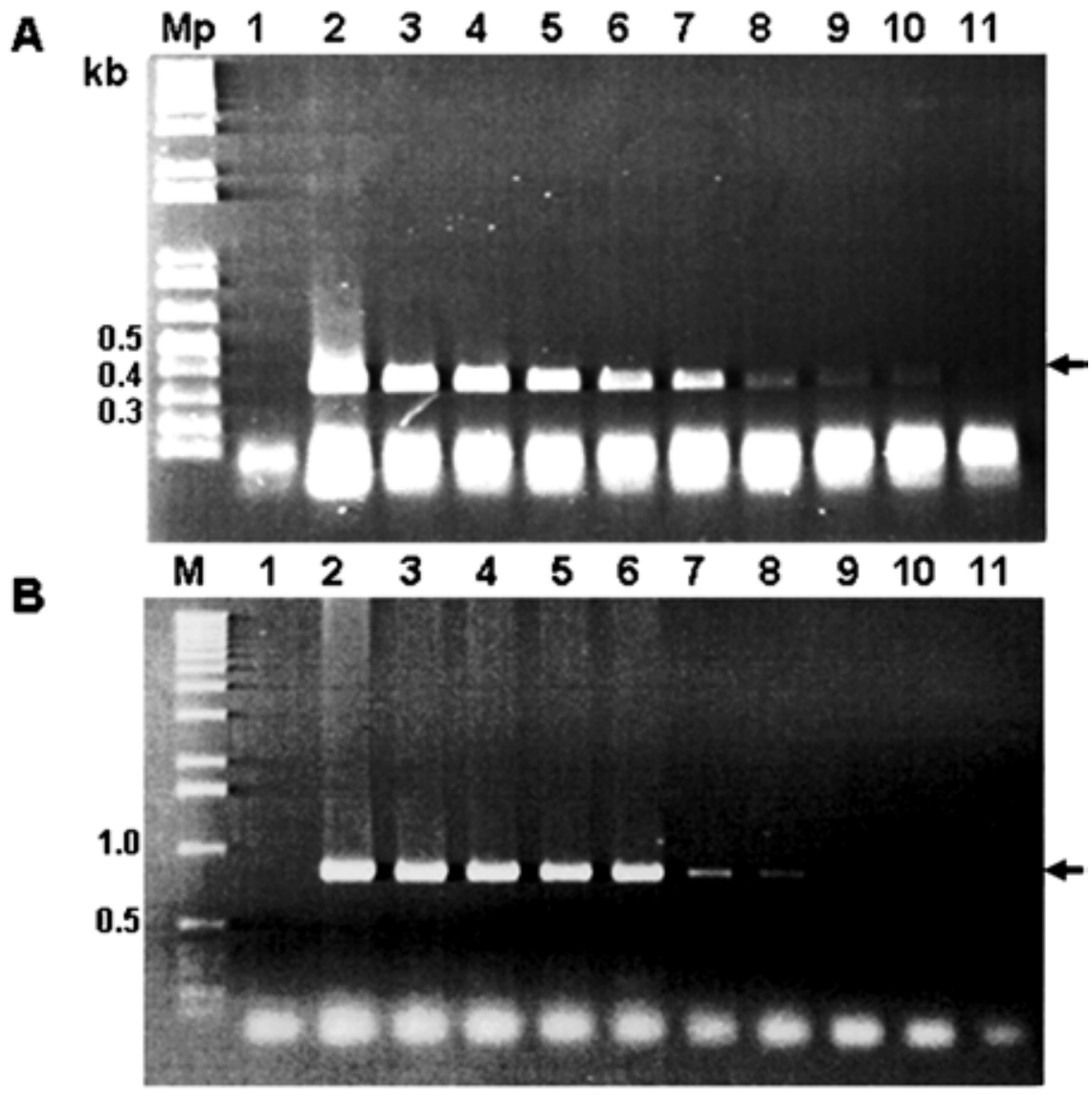

Fig. 2. Agarose gels showing the limits of polymerase chain reaction (PCR) detection for the $\mathbf{A}, 3 \mathrm{~S}$ and $\mathbf{B}, 9 \mathrm{~B}$ primer pairs. The primer pairs were used in the PCR with serial dilutions of total genomic DNA of Xanthomonas campestris pv. carotae (strain 108-2L2-1). Lanes Mp and M contain the DNA size markers, 1-kb Plus and the 1-kb DNA ladder, respectively (Gibco BRL). Lanes 1 to 11 contain 0 ng, $10 \mathrm{ng}, 1 \mathrm{ng}, 500 \mathrm{pg}, 125 \mathrm{pg}, 31 \mathrm{pg}, 9 \mathrm{pg}, 2 \mathrm{pg}, 488 \mathrm{fg}, 122 \mathrm{fg}$, and $31 \mathrm{fg}$ of total genomic DNA, respectively.

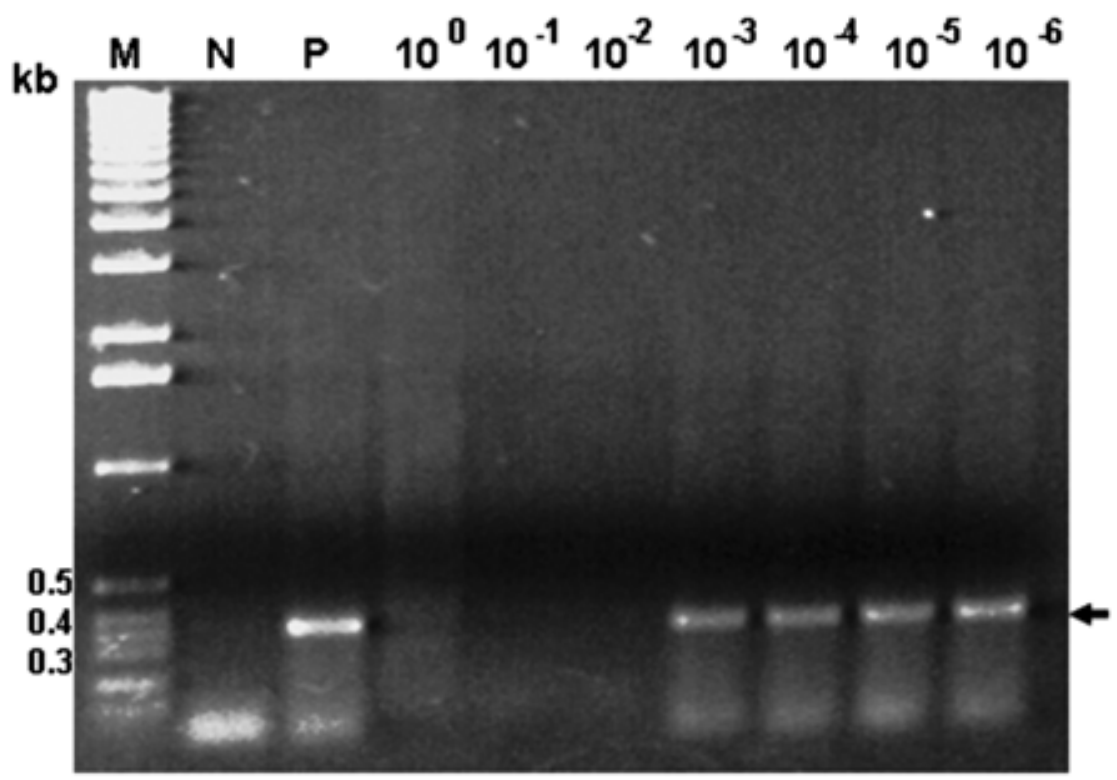

Fig. 3. Agarose gel showing polymerase chain reaction (PCR) detection of Xanthomonas campestris pv. carotae from leaves of carrot seedlings with bacterial leaf blight symptoms (artificially inoculated with strain 01C5L31). DNA extracts were prepared with the Qiagen DNeasy Plant Minikit, and PCR was performed with $3 \mathrm{~S}$ primer pair. Lane M contains the DNA size markers (1-kb DNA ladder, Gibco $\mathrm{BRL}$ ). Lane $\mathrm{N}$ is a negative control (PCR with a DNA extract from a symptomless control plant). $\mathrm{P}$ is a positive control (PCR with genomic DNA of $X$. campestris pv. carotae). Lanes $10^{0}$ to $10^{-6}$ represent PCRs with the indicated serial dilutions of the DNA extract. 
The $3 \mathrm{~S}$ and $9 \mathrm{~B}$ primer pairs were designed based on sequences of cloned RAPD fragments, an approach previously used to develop specific primers for detection of $X$. campestris pv. vitians (7). The nature of these RAPD fragments, in terms of the $X$. campestris pv. carotae genome, is unknown. However, the specificity of the primer pairs was established by the fact that the target DNA fragment was amplified from known $X$. campestris pv. carotae strains, but not from 13 other known $X$. campestris pathovars or four other species of bacteria. The 9B primer pair directed the amplification of the $\sim 900$-bp target fragment from most $X$. campestris $\mathrm{pv}$. carotae strains; however, an $\sim 2.0-\mathrm{kb}$ fragment was amplified from some strains, indicating some level of genetic diversity in this region of the genome. On the other hand, the $3 \mathrm{~S}$ primer pair directed the amplification of the $\sim 350$-bp target fragment from all $X$. campestris pv. carotae strains tested, indicating less genetic diversity in this region of the genome. Together with the finding that the $3 \mathrm{~S}$ primer pair was more sensitive than the $9 \mathrm{~B}$ primer pair, the $3 \mathrm{~S}$ primer pair was selected as the $X$.

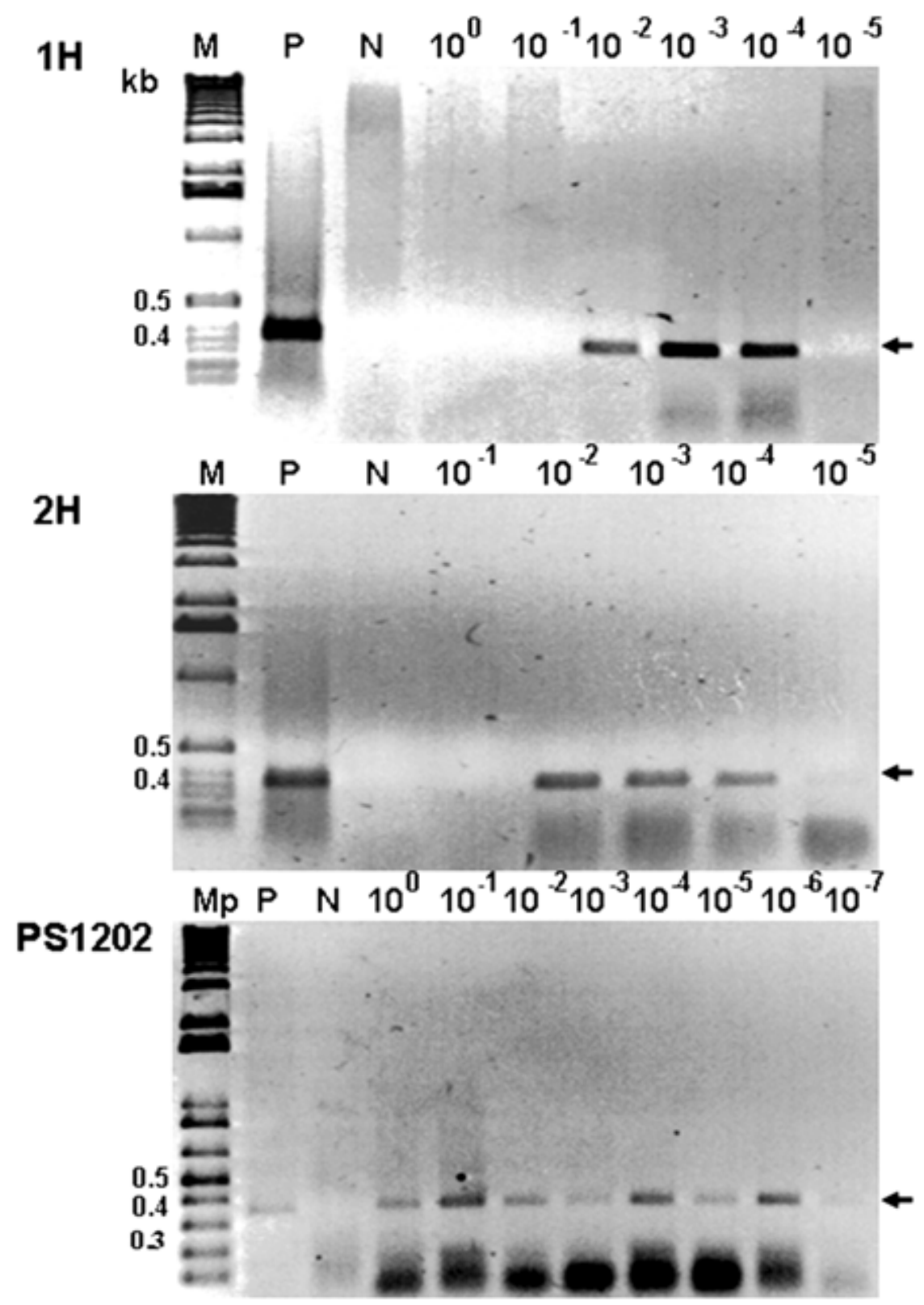

Fig. 4. Agarose gels showing polymerase chain reaction (PCR) detection of Xanthomonas campestris pv. carotae from contaminated carrot seed lots (seed lots $1 \mathrm{H}$ and $2 \mathrm{H}$ were produced in Oregon in 2001 and had contamination levels of $2.7 \times 10^{7}$ and $2.8 \times 10^{6} \mathrm{CFU} / \mathrm{g}$ of seed, respectively; and seed lot PS1202 was planted in Rosedale, CA, in 2002 and had a contamination level of $1.0 \times 10^{2} \mathrm{CFU} / \mathrm{g}$ of seed) with the PCR-based seed assay. DNA extracts were prepared from concentrated seed washate (pellets) with the Qiagen DNeasy Tissue Kit, and PCR was performed with the 3S primer pair. Lanes Mp and M contain DNA size markers, 1-kb Plus and the 1-kb DNA ladder, respectively (Gibco BRL). Lane $\mathrm{N}$ is a negative control (PCR with sterile $\mathrm{H}_{2} \mathrm{O}$ ). Lanes $10^{0}$ to $10^{-7}$ represent PCRs with the indicated serial dilutions of the DNA extract.

campestris pv. carotae-specific primer pair for this study.

The $3 \mathrm{~S}$ primer pair directed the amplification of the target fragment (i.e., the 350-bp fragment) from 816 X. campestris pv. carotae strains, including those from various geographical locations (California, Idaho, Oregon, Washington, and Canada) and substrates (infected plants and contaminated seeds). This included $785 X$. campestris pv. carotae-like colonies recovered from carrot plants with bacterial leaf blight symptoms and seed from California, Oregon, and Washington in 2001 and 2002. The $3 \mathrm{~S}$ primer pair also directed the amplification of the target fragment from a large number of $X$. campestris pv. carotae strains in Europe (M. Asma, personal communication). Together, these results indicate that the $3 \mathrm{~S}$ primer pair is a reliable tool for detection of $X$. campestris pv. carotae strains in most carrotproducing areas.

During the course of these experiments, the $3 \mathrm{~S}$ primer pair did not direct the amplification of the target DNA fragment from non-X. campestris pv. carotae-like bacteria (i.e., having different colony morphologies) isolated from carrot leaves and seeds. However, the $3 \mathrm{~S}$ primer pair directed the amplification of an $\sim 350$-bp fragment from an $X$. campestris pv. carotae-like bacterium isolated from a coriander seed lot produced in Idaho in 2002. Preliminary results indicated that this bacterium is a xanthomonad that is pathogenic on coriander and weakly pathogenic on carrot; however, it is genetically distinct from known $X$. campestris pv. carotae strains (A. Poplowsky, R. L. Gilbertson, and L. du Toit, unpublished results). This xanthomonad could be a distinct strain of $X$. campestris pv. carotae adapted to coriander or a different $X$. campestris pathovar that infects umbelliferous crops. This finding indicates the importance of continued testing of the $3 \mathrm{~S}$ primer pair with xanthomonads from other related crops and locations, as well as other bacteria to further define the specificity of this primer pair. Taken together, the results of PCR tests with $X$. campestris pv. carotae and other bacteria indicate that the $3 \mathrm{~S}$ primer pair is, for the most part, highly specific for $X$. campestris pv. carotae detection.

PCR with the $3 \mathrm{~S}$ primer pair could greatly reduce the time and facilities required for routine detection and identification of $X$. campestris pv. carotae and could be used in ecological and epidemiological studies. Thus, protocols were developed for the use of the $3 \mathrm{~S}$ primer pair and PCR for detection of $X$. campestris pv. carotae from various substrates. Using the boiledcell method to release the genomic DNA template, a large number of colonies can be tested in a short period of time $(\sim 6 \mathrm{~h})$. This method was used to confirm that 785 strains collected from carrot plants and seeds in 2001 and 2002 were $X$. campestris 
pv. carotae. PCR detection of $X$. campestris pv. carotae colonies provides many advantages, including rapid detection and differentiation of these colonies from nonpathogenic yellow bacteria sometimes isolated from carrot plants and seeds.

Because of the ubiquitous nature of $X$. campestris pv. carotae as a contaminant of carrot seed, it is important that all carrot seed lots be assayed for this pathogen, preferably before any type of treatment (e.g., hot water treatment or seed coating). However, the time-consuming and laborious nature of the seed-wash dilution plating assay makes this goal impractical. In our attempt to develop a more rapid seed assay, we found DAS-ELISA to be much less sensitive than the seed-wash dilution plating assay. Therefore, our efforts focused on development of a reliable PCRbased seed assay. In the development of this assay, it was first established that equivalent amounts of $X$. campestris pv. carotae were recovered from seed after 2-h and 16- to 18 -h washes. Thus, the washing time for both the standard seed wash and PCR-based seed assays can be reduced. From concentrated seed washate, all four
DNA extraction methods tested produced a DNA extract (template) that allowed for PCR amplification of the target fragment with the $3 \mathrm{~S}$ primer pair. However, the DNA extracts generated with all four methods had to be diluted for reliable PCR amplification of the target fragment, indicating that PCR inhibitors were present in these carrot seed extracts. The presence of PCR inhibitors was previously reported in the development of a PCR assay for detection of Alternaria radicina from carrot seed (16). Because the commercially available Qiagen DNeasy Tissue Kit provided a DNA extract that allowed for consistent amplification of the target fragment, it was selected as the standard method to prepare the DNA template for the PCR-based seed assay. Using this assay, $X$. campestris pv. carotae was detected from seed lots with contamination levels ranging from $2 \times 10^{2}$ to $2.3 \times 10^{8} \mathrm{CFU} / \mathrm{g}$, which is in the range of detection of the seed-wash dilution plating assay. It is significant that there was good correlation between results obtained for the PCR-based seed assay and the seed-wash dilution plating assay. Thus, all seed lots that tested positive by the seed-

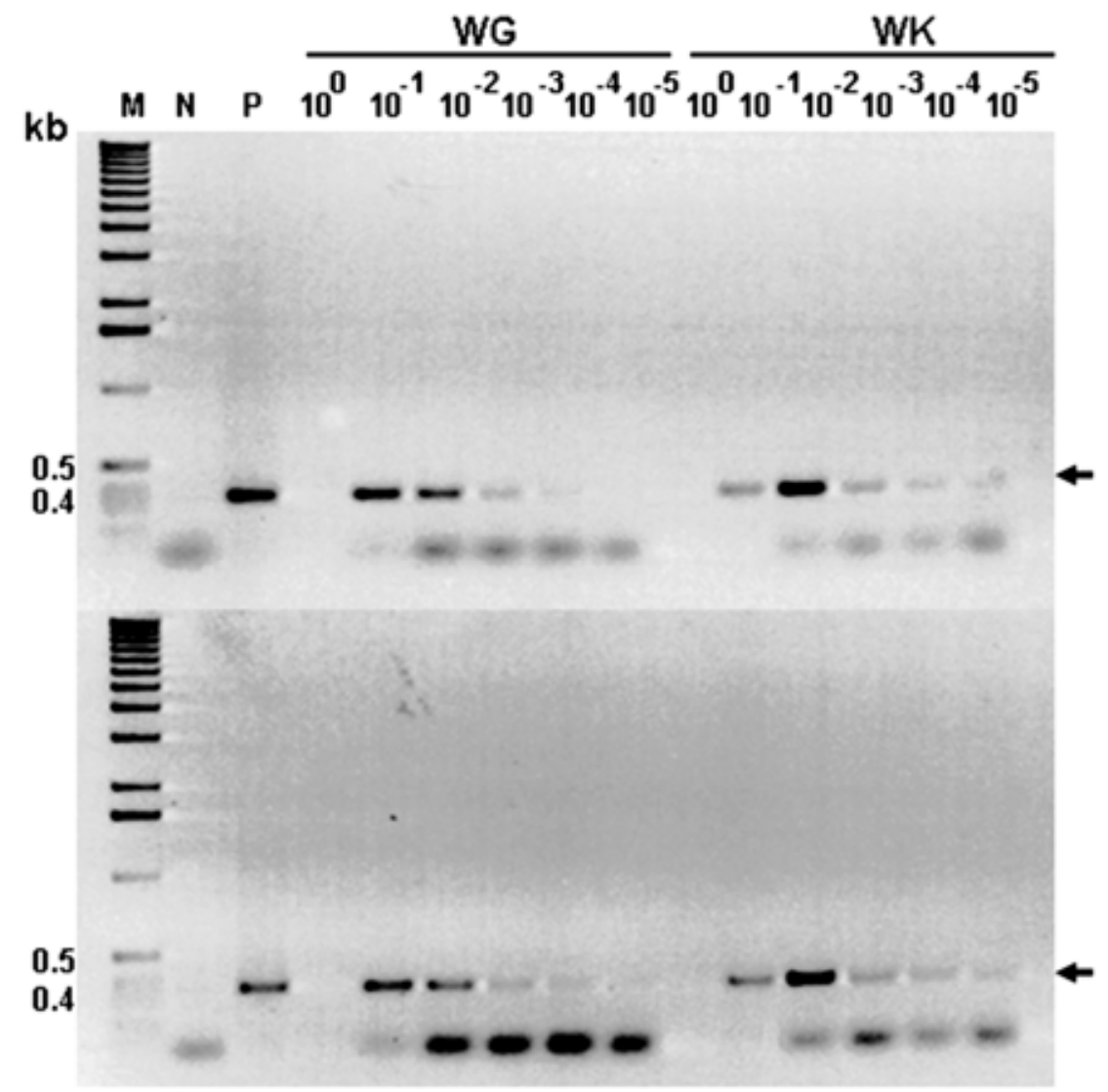

Fig. 5. Agarose gels showing polymerase chain reaction (PCR) detection of Xanthomonas campestris pv. carotae from two contaminated carrot seed lots (seed lots WG and WK were produced in Washington and had contamination levels of $1.1 \times 10^{6}$ and $2.3 \times 10^{7} \mathrm{CFU} / \mathrm{g}$ of seed, respectively). The PCR-based seed assays involved either a $16-$ to 18 -h at $4^{\circ} \mathrm{C}$ wash (upper gel) or a 2 -h at room temperature wash (lower gel). DNA extracts were prepared from concentrated seed washate (pellets) with the Qiagen DNeasy Tissue Kit, and PCR was performed with the 3S primer pair. Lane M contains the DNA size markers (1-kb DNA ladder, Gibco BRL). Lane N is a negative control (PCR with sterile $\mathrm{H}_{2} \mathrm{O}$ ). Lane $\mathrm{P}$ is a positive control (PCR with genomic DNA of $X$. campestris pv. carotae). Lanes $10^{0}$ to $10^{-5}$ represent PCRs with the indicated serial dilutions of the DNA extracts.

wash dilution plating assay were also positive by the PCR-based assay, but no lots tested positive by PCR and negative by the seed-wash dilution plating assay or vice versa. Thus, this PCR-based seed assay shows promise for routine detection of $X$. campestris pv. carotae from carrot seed.

There are also disadvantages to the PCR-based seed assay, including the inability to differentiate viable versus nonviable cells, the presence of PCR inhibitors, and the lack of a quantitative component of the test. Because the PCR test detects pathogen DNA, it is possible that free DNA from nonviable bacteria can be detected, thereby giving a false positive result. Indeed, this was demonstrated with the PCR detection of $X$. campestris pv. carotae (presumably DNA) from hot water treated seed from which no viable bacteria were recovered. Nevertheless, detection of the DNA from a seed lot demonstrates a history of contamination, which would indicate the need for further assay and/or treatment. The presence of PCR inhibitors was solved by using a series of dilutions of the seed pellet DNA extracts. Quantification is important because bacterial leaf blight is not a zero tolerance disease, and lower levels of contamination (i.e., $<10^{4}$ $\mathrm{CFU} / \mathrm{g}$ ) may not give rise to significant disease in the field (23). The development of a quantitative PCR-based assay (e.g., real-time PCR) could address this issue. Taking these issues into consideration, we envision an approach where, prior to treatment, carrot seed lots would be tested by PCR. Positive lots would be assayed additionally with the seed-wash dilution plating assay. Lots confirmed to be contaminated would be subjected to treatment (e.g., hot water) and follow-up confirmatory seed wash assays.

In summary, PCR-based assays with the $3 \mathrm{~S}$ primer pair were developed for rapid detection of $X$. campestris pv. carotae from different substrates, including carrot tissues and seeds. The $3 \mathrm{~S}$ primer pair is highly specific and detected all known strains. These PCR-based assays have the potential to improve routine detection of this important carrot pathogen.

\section{ACKNOWLEDGMENTS}

This study was partially supported by grants from the California Carrot Advisory Board. We thank F. Crowe, L. du Toit, M. Derie, and J. J. Nunez for assistance in collecting carrot plant and seed samples.

\section{LITERATURE CITED}

1. Adachi, N., and Oku, T. 2000. PCR-mediated detection of Xanthomonas oryzae pv. oryzae by amplification of the $16 \mathrm{~S}-23 \mathrm{~S}$ rDNA spacer region sequence. J. Gen. Plant Pathol. 66:303309.

2. Alvarez, A. M., and Lou, K. 1985. Rapid identification of Xanthomonas campestris pv. campestris by ELISA. Plant Dis. 69:10821086.

3. Ark, P. A., and Gardner, M. W. 1944. Carrot bacterial leaf blight as it affects roots. Phytopathology 34:416-420. 
4. Audy, P., Laroche, A., Saindon, G., Huang, H. C., and Gilbertson, R. L. 1994. Detection of the bean common blight bacteria, Xanthomonas campestris pv. phaseoli and X. c. phaseoli var. fuscans, using the polymerase chain reaction. Phytopathology 84:1185-1192.

5. Avrameas, S. 1969. Coupling of enzymes to proteins with glutaraldehyde. Use of the conjugates for the detection of antigens and antibodies. Immunochemistry 6:43-52.

6. Barak, J. D., and Gilbertson, R. L. 2003. Genetic diversity of Xanthomonas campestris pv. vitians, the causal agent of bacterial leafspot of lettuce. Phytopathology 93:596-603.

7. Barak, J. D., Koike, S. T, and Gilbertson, R. L. 2001. Role of crop debris and weeds in the epidemiology of bacterial leaf spot of lettuce in California. Plant Dis. 86:169-178.

8. Blodgett, E. C. 1944. Carrot disease in Idaho in 1943. Plant Dis. Rep. 28:764-769.

9. Davis, R. M., and Raid, R. N. 2002. Compendium of Umbelliferous Crop Diseases. American Phytopathological Society, St. Paul, MN.

10. Dellaporta, S. L., Woods, J., and Hicks, J. B. 1983. A plant minipreparation, Version II. Plant Mol. Biol. Rep. 1:19-21.

11. Glick, D. L., Coffey, C. M., and Sulzinski, M. A. 2002. Simultaneous PCR detection of the two major bacterial pathogens of geranium. J. Phytopathol. 150:54-59.

12. Hartung, J. S., Daniel, J. F., and Pruvost, O. P.
1993. Detection of Xanthomonas campestris pv. citri by the polymerase chain reaction method. Appl. Environ. Microbiol. 59:11431148.

13. Kado, C. I., and Heskett, M. G. 1970. Selective media for isolation of Agrobacterium, Corynebacterium, Erwinia, Pseudomonas, and Xanthomonas. Phytopathology 60:969-976.

14. Kuan, T.-L., Minsavage, G. V., and Gabrielson, R. L. 1985. Detection of Xanthomonas campestris pv. carotae in carrot seed. Plant Dis. 69:758-760.

15. Pfleger, F. L., Harman, G. E., and Max, G. A. 1974. Bacterial leaf blight of carrots: Interaction of temperature, light and inoculum procedures on disease development of various carrot cultivars. Phytopathology 64:746-749.

16. Pryor, B. M., and Gilbertson, R. L. 2001. A PCR-based assay for detection of Alternaria radicina on carrot seed. Plant Dis. 85:18-23.

17. Saad, S. M., and Wade, E. K. 1972. Bacterial blight of carrot in Wisconsin. Plant Dis. Rep. 56:744-746.

18. Sambrook, J., Fritsch, E. F., and Maniatis, T. 1989. Molecular Cloning: A Laboratory Manual. 2nd ed. Cold Spring Harbor Laboratory, Cold Spring Harbor, NY.

19. Schaad, N. W., and Stall, R. E. 1988. Xanthomonas. Pages 81-94 in: Laboratory Guide for Identification of Plant Pathogenic Bacteria. N. W. Schaad, ed. American Phytopathological
Society, St. Paul, MN

20. Sulzinski, M. A., Moorman, G. W., Schlagnhaufer, B., and Romaine, C. P. 1997. A simple DNA extraction method for PCR-based detection of Xanthomonas campestris pv. pelargonii in geraniums. J. Phytopathol. 145:213-215.

21. Sulzinski, M. A., Moorman, G. W., Schlagnhaufer, B., and Romaine, C. P. 1998. PCR based detection of artificial latent infections of geranium by Xanthomonas campestris pv. pelargonii. J. Phytopathol. 146:111-147.

22. Toth, I. K., Hyman, L. J., Taylor, R., and Birch, P. R. J. 1998. PCR-based detection of Xanthomonas campestris pv. phaseoli var. fuscans in plant material and its differentiation from X. c. pv. phaseoli. J. Appl. Microbiol. 85:237-336.

23. Umesh, K. C., Davis, R. M., and Gilbertson, R. L. 1998. Seed contamination thresholds for development of bacterial leaf blight of carrots caused by Xanthomonas campestris pv. carotae. Plant Dis. 82:1271-1275.

24. Wang, H., Qi, M., and Cutler, A. J. 1993. A simple method for preparing plant samples for PCR. Nucleic Acids Res. 21:4153-4154.

25. Watson, R. D. 1948. Carrot bacterial blight control in Idaho. Plant Dis. Rep. 32:238-239.

26. Zhang, Y. P. 1996. Etiological study of cherry stem pitting disease and molecular characterization of sour cherry green ring mottle virus. $\mathrm{Ph} . \mathrm{D}$. diss. University of California, Davis. 